\title{
ALI SHEHZAD ZAIDI
}

\section{A selection of Poems by Faiz Ahmed Faiz}

(Translated from the Urdu by Daud Kamal)

The Grove 13 (2006)

\section{Dedication}

\author{
Abacus of suffering - \\ frost-edged fields \\ of withered flowers - \\ a wilderness of yellow leaves. \\ This is my land - \\ offal in narrow lanes. \\ I write \\ for the miserable - \\ clerks, postmen, coolies, \\ labourers with bent knees, \\ peasants in the blistering sun. \\ It is for the widows \\ I write - \\ for the orphans \\ and the unwed - \\ for the condemned \\ in their separate cells \\ and the stars \\ that will not last \\ through the night.
}




\section{A Prison Evening}

Night — enchanting princess — descends the sky's jewelled staircase one step at a time.

A cool breeze whispers words of love.

Gnarled and hunchbacked trees in the prison compound are embroidering exquisite designs on the sky's blue silk shawl. Moonlight penetrates my soul.

Green undulating shadows star-moisture - the poignancy of desire.

How precious is life!

But the tyrants

have injected their venom

into the veins of humanity.

They have slaughtered our joy.

Centuries of oppression, brutality, plunder.

And, yet, the moon shines

in all her splendour.

The lotus blooms.

Life is eternal.

\section{Captivity}

What does it matter

if pen and paper have been snatched from my hands?

I have dipped

my fingers

in the blood of my heart.

What does it matter

if my lips

have been sealed?

I have put

a tongue

in every mouth of my chain. 


\title{
Disillusionment
}

\author{
Endeavour \\ has now been squeezed bone-dry \\ of possibility - \\ even the most intrepid eagle \\ cannot pierce \\ the sky's ultimate barrier. \\ All the stars have been lassoed \\ one by one \\ and the moon-goddess \\ strangled to death \\ by an unrepentant Othello. \\ No dewdrop of grace \\ trembles on the eye's periphery - \\ no diaphanous dream \\ soothes the heart. \\ Those ravishing lips are gone - \\ free hearts and illumined minds \\ have atrophied. \\ Love \\ you will moulder in your grave \\ and $\mathrm{I}$ in mine. \\ There is no antidote \\ to death's scorpion-sting.
}




\section{A Selection of Poems by Daud Kamal}

\section{The Rebel}

They

stood him up

against an orchard wall

and shot him

at dawn.

Pandemonium of crows

and then

the empty horizon.

Hundreds of miles away

his mother

kneels in prayer -

in ignorance -

the ignorance of prayer.

Wheat ear on the stubble -

the blind earth

must be fed. 


\title{
Anniversary
}

\author{
Cascading back \\ to the source \\ over a difficult terrain \\ but the heart remembers. \\ Wet stones \\ conscious of their lineage - \\ the chopped-up moon \\ in paddy-fields.
}

A fierce love has blurred my sight

and burnt the lines off

the palms of my hands.

I have drunk acrid milk.

I have heard the sound of clogs

in an ancient ruin.

How can the mind contend

with all this chaos -

this endless repetition

of thwarted lives?

Shelley asserts

that the deep truth

is imageless.

An invisible bird

perches on my shoulder

and speaks to me

in a language

I do not understand.

Ashes and dust.

I am only a word-smith. 


\title{
Kingfisher
}

\author{
April \\ is the kingfisher's beak \\ which pierces \\ the river's glad torment. \\ Is this an image \\ of our love? \\ Carnage \\ in the rose-valleys \\ under the first light \\ of our wounds. \\ Clouds \\ detach themselves \\ from disconsolate trees. \\ The future \\ curves on another shore. \\ Tongues of water \\ cradle our startled dreams. \\ Moss-grown stepping-stones. \\ The stars burn fiercely. \\ They tell us what we are.
}




\section{Winter Rain}

Mist

suspended over a deep void:

translucent bridge

sculpted in fire -

in rock-crystal.

Memory,

someone says,

is a forest of mirrors.

Is this true?

Stone parapets

eroded by time.

Is death

the only exit?

The moon thaws

before your loveliness:

you are the breath of violets -

the vivacity

of a snow-fed stream.

Nightbound travelers -

you and me -

and this winter rain. 


\section{A Selection of Poems by Daud Kamal \\ The Grove 17 (2010)}

\section{Floods}

How does one forgive

the treachery

of blind rivers

and water-buffaloes

dissolving in the mind?

Their hut was

forty years old.

They had

three wooden boxes of dowry

and a sackful of expensive rice.

At the army relief-camp, the bride-to-be covers her head while her parents look the other way.

\section{A Narrow Valley}

Flash-flood

in a narrow valley.

A bowl of milk

Falls

From the hands

Of a trembling child.

Mud houses collapse.

Prayers

Do not work

At time

Such as these. 


\title{
Widow
}

\author{
Every evening \\ she would go down to the river \\ wet pebbles and hird-shadows \\ but the boat \\ never came.
}

Mist like a shroud

and the smoke of cowdung

over which

she cooks for her children the river, the river.

The youngest asks:

how much bigger than a scorpion is death? You should be out with the others - she scolds catching fish.

Mouth stained by an old dream - glass bangles and the sounds of a village festival in her eyes, in her blood the river, the river. 


\section{Fxile, Prisoner, Poet: A Brief History of Faiz Ahmed Faiz}

The Grove 25 (2018-2020)

The artistic sensibility of Faiz Ahmed Faiz (1911-1984), Pakistan's most acclaimed and translated Urdu poet, was a rare synthesis of modernity and tradition. After completing master's degrees in Arabic and English in the early nineteen thirties, Faiz taught English as a lecturer at colleges in Amritsar and Lahore. He served as the editor of an Urdu literary journal for two years and joined the Progressive Writers Association of India at its inception in 1936. As he recalls in an autobiographical essay, the Great Depression ushered in a period of intellectual ferment in the Indian subcontinent:

It was a time of great creativity and the opening of new perspectives. I think the first lesson I learnt was that it was impossible to detach oneself from what was happening externally. An individual, no matter how rich and fulfilled emotionally and in intellectual terms, is, after all, only an individual, a small, humble entity of little consequence. What matters is the world outside and the people in it and what happens to them. What is important is the larger human equation of pain and pleasure. As such, internal and external experiences are two sides of the same coin. ("Faiz on Faiz" 4-5)

Faiz became a literary celebrity in 1941 when Naqsh-i-Faryadi, his first volume of Urdu poetry, was published. However, World War Two intervened, and in 1942, Faiz joined the British Army War Publicity Department in Delhi. Upon leaving military service in 1947, the year of Pakistan's independence, Faiz became the editor of The Pakistan Times. Amidst a government crackdown on leftists, Faiz was imprisoned in solitary confinement from 1951 until 1955.

In the coming years, many other worthy endeavors of Faiz would be interrupted by imprisonment, exile, or calamity. Faiz's poems express the anguish of separation - be it of India from Pakistan, East Pakistan from West Pakistan, husband from wife, poet from country - as in "Legend of a Tall Tree": 
It seems there is nothing now -

Neither sun nor moon -

Neither darkness nor dawn.

There's no Aphrodite in the sea-foam -

No ship in the harbour of pain.

Perhaps this was all an illusion -

Legend of a tall tree -

The last swirl of desolation

In the butchered lane.

No one will come now to this oasis -

No one will drink from this stream.

All attachments are snapped -

All friendships buried.

This is the worst that could have been.

But courage - my heart -

This too will pass.

Do not despair.

There's a life to live.

(Four Contemporary Poets 11)

Faiz co-founded the Afro-Asian Writers Movement at a time when Third World writers were de-colonizing the imagination as can be seen in Faiz's "Come Back Africa":

Come back Africa.

I've heard the thunder

of your drums.

Your maddening rhythms

have entered my blood.

Come back Africa.

I've raised my forehead

from the dust.

I've peeled off

the scales of suffering

from my eyes.

Come back Africa.

I've smashed

the shackles of pain.

I've torn

the web of helplessness.

(Four Contemporary Poets 27)

Upon his return to Pakistan from its first conference, held in Tashkent in 1958, Faiz was imprisoned for six months by the newly-installed military regime of General Ayub Khan. In 1978, in the wake of the military coup that overthrew the democratically elected government of Zulfiqar Ali Bhutto, Faiz moved to Beirut to serve as the editor of Lotus, the flagship literary journal of the Afro-Asian 
Writers Movement. He had to leave Beirut because of the Israeli invasion of Lebanon in 1982. Faiz died shortly after his return to Pakistan in 1984.

\section{Works Cited}

Faiz, Faiz Ahmed. "Faiz on Faiz.” Tr. Khalid Hasan. In Faiz in English. Tr. Daud Kamal. Karachi: Pakistani Publishing House, 1984.

Faiz, Faiz Ahmed, Ahmed Faraz, Munir Niazi, and Ahmed Nadeem Qasimi. Four Contemporary Poets. Tr. Daud Kamal. Islamabad: National Book Foundation, 1992. 


\section{Daud Kamal's Legacy of Mercy}

"A poet's autobiography," according to Yevgeny Yevtushenko, "is his poetry. Anything else is just a footnote" (1). Even so, a brief introduction to the Pakistani English-language poet Daud Kamal is in order. Born in Abottabad in 1935 to a Hindko-speaking family, Kamal was educated at the Burn Hall School in Srinagar and completed a bachelor's degree in English at Islamia College in Peshawar. In 1956, he left for Cambridge University, where he completed a tripos (three-part examination) in English literature for his master's degree. Two years later, Kamal returned to Pakistan. He began teaching in the Department of English and Modern European Languages at the University of Peshawar which would soon thrive under its Vice Chancellor, Chaudhry Mohammad Ali (Kamal's father) who promoted women's education at the university, establishing the Jinnah College for Women in 1964. Kamal taught for nearly three decades in the English Department, serving as department chair during the nineteen eighties. The department chairs who preceded him, such as Herbert Michael Close, Mazhar Ali Khan, and Margaret Harbottle, were all gifted teachers and revered by their students. Near the end of his life, Kamal recalled, only half in jest, having gone into teaching out of "an exaggerated sense of idealism coupled with a total lack of a world-sense."1

Kamal's first volume of original poetry was a self-published chapbook titled The Compass of Love (1973). During Kamal's lifetime, Peter Dent, the head of the Interim Press, a small poetry press in the United Kingdom, published Kamal's Recognitions (1979) and A remote beginning (1985), and also included several of Kamal's poems in an anthology of Pakistani English-language poetry titled The Blue Wind (1984). Kamal was an accomplished translator of classical and modern Urdu poetry. He died of a heart attack in December 1987 while on a visit to the United States that was sponsored by the United States Information Agency. His posthumous volumes include Rivermist (1992), Before the Carnations Wither (1995) and A Selection of Verse (1997).

Kamal's "Old Woman" resurrects the merciful ethos of the Sufi mystical tradition. While I was his student at the University of Peshawar in the early eighties, Kamal would, on his way to photocopy his poems at a shop, pause to converse with an old woman and give alms to her. In this poem, she lives on, together with the poet persona who is an oasis in a desert of indifference. "The need to lend a voice to suffering," according to Theodore W. Adorno, "is the

\footnotetext{
${ }^{1}$ Unpublished July 25, 1985 letter to the journalist Khalid Hasan.
} 
condition of all truth" (17-18); and in "Old Woman," Kamal indicts a social system that creates suffering:

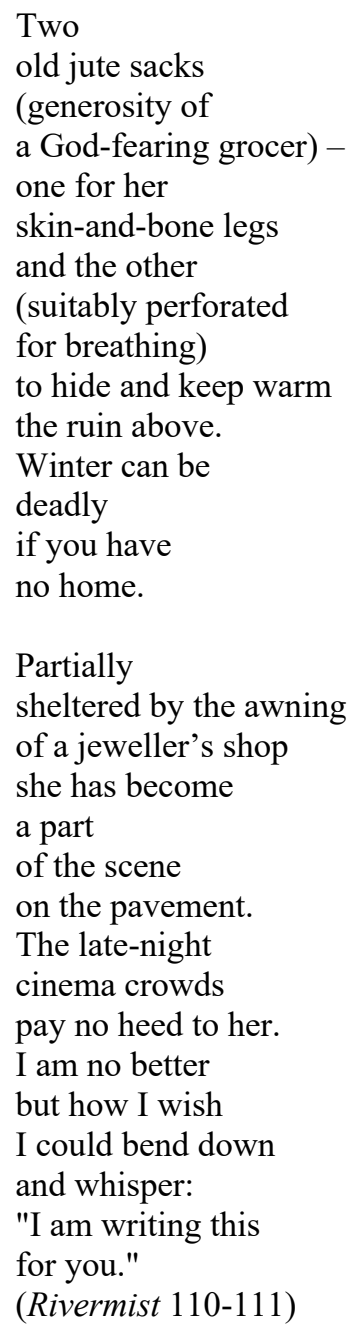

The poem's opening word has a line to itself. "Two" modifies more than the two jute sacks, connoting at once the unity and the separation between the poet and the old woman. They meet under the awning of the shop of a jeweler, perhaps the one who created the jewels of caring and love. The poem's final word rhymes with the first one. At first glance the "you" appears to be the old woman, but on further consideration "you" might well address the reader, the indifferent cinema crowds, or the divinity that erases distinctions. 
Kamal condenses Guy Debord's The Society of the Spectacle in the two lines about the cinema crowds who ignore the old woman. Debord shows how society diverts our gaze away from human need and suffering and towards a spectacle that is "a visible negation of life" [whose] "function in society is the concrete manufacture of alienation" $(14,23)$. The lachrymose spectacles in our cinema and public life are, in the words of Debord, "a specious form of the sacred" and the "the locus of illusion and false consciousness" (12).

As a messenger of mercy, Kamal bore witness to barbarism that recurs throughout the ages. In his poems, an object or artifact opens a wondrous portal that leads us to a wistful sense of what might have been. In "A Rotting Pomegranate," pomegranate seeds that resemble fragments of shattered pottery evoke the sackings of Baghdad, then a great center of learning:

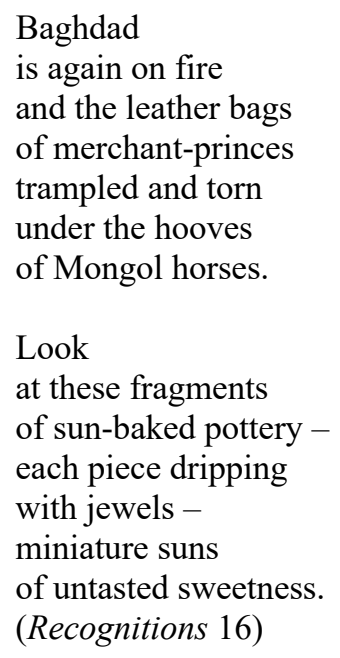

The ruby-red pomegranate color denotes the bloodshed during the massacres by the Mongol hordes of Helagu in 1258 and of Tamerlane in 1401, those avatars of "shock and awe." However, the image of the pomegranate also promises regeneration, fecundity, and immortality (Cooper 134). 


\section{Works Cited}

Adorno, Theodor W. Negative Dialectics. New York: Seabury Press, 1973.

Cooper, J. C. An Illustrated Dictionary of Symbols. London: Thames and Hudson, 1978.

Debord, Guy. The Society of the Spectacle. New York: Zone Books, 1994.

Kamal, Daud. Recognitions. Budleigh Salterton, U. K.: Interim Press, 1979.

---. Rivermist. Islamabad: National Book Foundation, 1992.

Yevtushenko, Yevgeny. A Precocious Autobiography. Tr. Andrew R. McAndrew. New York: E. P. Dutton, 1963.

Ali Shehzad Zaidi teaches Spanish language at the State University of New York at Canton. He co-founded the Transformative Studies Institute in 2007 and is the editor of its quarterly journal, Theory in Action. 